\title{
Sexual Dimorphism Determination from the Lineal Dimensions of Skulls
}

\author{
Determinación del Dimorfismo Sexual utilizando las Dimensiones Lineales del Cráneo
}

"Daniela Alejandra Zavando Matamala; ",** Iván Claudio Suazo Galdames \& * Ricardo Luiz Smith

ZAVANDO, M. D. A.; SUAZO, G. I. C. \& SMITH, R. L. Sexual dimorphism determination from the lineal dimensions of skulls. Int. J. Morphol., 27(1):133-137, 2009.

SUMMARY: The sex determination from human skulls can be made by means of morphologic and morphometric methods have been broadly studied. These methods contribute with objective data; however, they present interpopulational variability. The purpose of this article is to determine sexual dimorphism using lineal dimensions in a sample of human skulls collection belonging to the Universidade Federal de São Paulo (UNIFESP), calculating the discriminant function. To complete the selection approaches, 226 skulls were analyzed. Mensurements were carried out among the following reference points of the skull: right Eurion- left Eurion (Eu - Eu), GlabellaOpisthocranion (Gla - Op), Basion - Bregma (Ba-Br), Nasion - Prosthion (Na-Pr), Bizigomatic (Zi-Zi), Maximal width of the piriform aperture (MWPA), and Nasion - Spinal (Na-ANS). Descriptive and inferential statistics (student's t-test proved $p<0.05$, analysis of discriminant function) for sex were calculated. Statistically significant differences were seen in the following dimensions: Gla - Op, Na - Pro, Zi - Zi, and Na - ANS. Only for the distances Zi - Zi and Na-ANS, a discriminant function with a yield of $82 \%$ was identified for the correct classification for sex. The authors conclude that the lineal dimensions present a limited utility for sexual dimorphism in this sample.

KEY WORDS: Craniometrics points; Skull; Sexual dimorphism; Discriminant function.

\section{INTRODUCTION}

It is possible to determine sex from isolated bony pieces such as the temporary bone, frontal, in jaw, in orbit, and in tooth of the skull by studying a group of traditional morphological indicators or through the calculation of general cranial dimensions and the angles formed among craniometric points (Baughan \& Demirjian, 1978, Lestrel et al., 2005; Ursi et al., 1993; Olivier \& Tissier, 1977; Bibby, 1979; Kalmey \& Rathbun, 1996; de Paiva \& Segre, 2003; Kemkes \& Gobel, 2006; Celbis et al., 2001; Wescott \& Moore-Jansen, 2001; Panella et al., 1988; Buschang et al., 1986; Rosas et al., 2002; Steyn \& Iscan, 1998; Franklin et al., 2007; Schmittbuhl et al., 2001; Loth \& Henneberg, 1998; Loth \& Henneberg, 1996; Balci et al., 2005; Haun, 2000; Lam et al., 1996; Graw et al., 1999; Schleyer et al., 1971; Introna et al., 1993; Kondo et al., 2005; Abdelmalek \& Michael, 1984).

The previous parameters, not so much qualitative as the quantitative ones, deserve special consideration, because the variation of the skeletal characteristics of different populations (Steyn \& Iscan). In relation to these, Franklin et al. (2005) in a study of skulls belonging to South Africans evidenced indigenous, distinctive features between men and women, some of which have not been described for the caucasian population. Jointly they reported the impossibility of establishing the presence of sexual dimorphism starting from the classic indicators described by Krogman (1955). Complementarily, other authors have described the influence of the size and the intrasexual variations in certain populations, such as the case of the caucasian population of North America (Kimmerle et al. 2008). This shows lack of accuracy in the diagnosis of the sex using the traditional methods described by Krogman.

The purpose of this study was to use dry human skulls to anthropologically determine sexual dimorphism in conventional lineal dimensions, to build a discriminant function, and to evaluate its yield; the skulls used for the study were from the Collection of the Museum of Skulls of the Universidade Federal de São Paulo.

\footnotetext{
* Departamento de Morfología y Genética, Universidade Federal de São Paulo, Brasil.
}

** Departamento de Anatomía Normal, Universidad de Talca, Chile. 


\section{MATERIAL AND METHOD}

A cross sectional study was carried out using a nonprobabilistic method. From Universidade Federal de São Paulo's collection the collection in the (UNIFESP), 226 mature human skulls that conformed to the eligibility criterion were analyzed; the criterion was that the conservation state of the skulls should allow obtaining the proposed measurements. These skulls corresponded with mature individuals with sex and age record. In this analysis, skulls that presented asymmetries or evident dismorphosis, fracture or loss of some segment of the bony head were excluded.

The sample comprised 149 males skulls with a mean of age of 43.41 years old (DS 12.88) and 77 females skulls with a mean of age of 38.19 years old (DS 15.68). This sample considered skulls from individuals with white, brown, and black skin.

The mensurations were carried out in the museum of skulls of UNIFESP with the aid of a Willis compass $(0.1 \mathrm{~mm})$ and a digital caliper $(0.01 \mathrm{~mm})$. The following lineal dimensions of the skulls were determined:

- Bieuric (Eu-Eu).

- Glabela - Opisthocranion (Gl-Op).

- Basion - Bregma (Ba-Br).

- Nasion - Prosthion (Na-Pr).

- Bizigomatic (Zi-Zi).

- Maximal width of the piriform aperture (MWPA).

- Nasion - Spinal (Na-ANS).
With the obtained dimensions and using the statistical program SPSS 15.0 for Windows, descriptive statistics were calculated. The mean differences were contrasted by means of $\mathrm{T}$ test for independent samples, with $\mathrm{p}<0.05$. With the purpose of obtaining the lineal dimensions that better allow discriminating between skulls of men and women, the analysis of the discriminant function was carried out using the inclusion method for steps and correcting the calculation in the differences in the skull sizes of both groups. Finally, to determine the combinations of lineal dimensions that better explains the variance among the groups, principal components analysis was carried out.

\section{RESULTS}

The means of all the analyzed lineal dimensions were bigger in the men skulls than in the women skulls. Nevertheless only Gl-Op, Na-Pr, Zi-Zi, and Na-SNA were statistically significant with $\mathrm{p}<0.05$. These results are shown in Table I.

When carrying out the calculation of the lineal discriminant functions of Fischer, it was observed that in an independent way, only the distance $\mathrm{Zi}$ - $\mathrm{Zi}$ and $\mathrm{Na}$-SNA allow to discriminate against. Table II shows the sample classification coefficients that compose the discriminant function; the percentage of skulls correctly classified with this function was $82.7 \%$.

Table I. Statistical analysis, t Student, for dimensions by sex.

\begin{tabular}{llcccc}
\hline Dimension & Sex & $\mathrm{n}$ & Mean & DS & Sig. (bilateral) \\
\hline Bieuric & Male & 149 & 140.86 & 10.757 & \multirow{2}{*}{040} \\
Glabella - Opisthocranio & Female & 77 & 137.66 & 11.581 & \\
& Male & 149 & 184.09 & 10.529 & .001 \\
Basión - Bregma & Female & 77 & 178.81 & 11.931 & \\
& Male & 149 & 134.99 & 9.972 & \multirow{2}{*}{ Nasion - Prosthion } \\
Female & 77 & 133.64 & 11.694 & \\
Bizigomatic & Male & 149 & 68.846 & 5.4118 & \multirow{2}{*}{000} \\
Maximal width of the piriform aperture & Female & 77 & 64.492 & 5.0839 & \\
& Male & 149 & 127.02 & 5.972 & .000 \\
Nasion - Spinal & Female & 77 & 25.145 & 2.5098 & .066 \\
& Male & 149 & 51.250 & 3.8834 & \\
& Female & 77 & 47.613 & 3.1458 & .000 \\
\hline
\end{tabular}


Table II. Coefficients of classification of the discriminant function.

\begin{tabular}{lrc}
\hline Dimension & \multicolumn{2}{c}{ Sex } \\
\hline & Male & Female \\
Bizigomática & 3.741 & 3.528 \\
Nasion - Spinal & 3.238 & 2.997 \\
(Constant) & -320.980 & -283.486 \\
\hline
\end{tabular}

When carrying out the analysis of the principal components obtained for the first three components, the results are able to explain $76.36 \%$ of the variance in the dimensions of the analyzed male skulls and $76.9 \%$ of the variance in skulls of women. The details of these results are given in Table III.

Table III. The principal components analysis dimensions by sex.

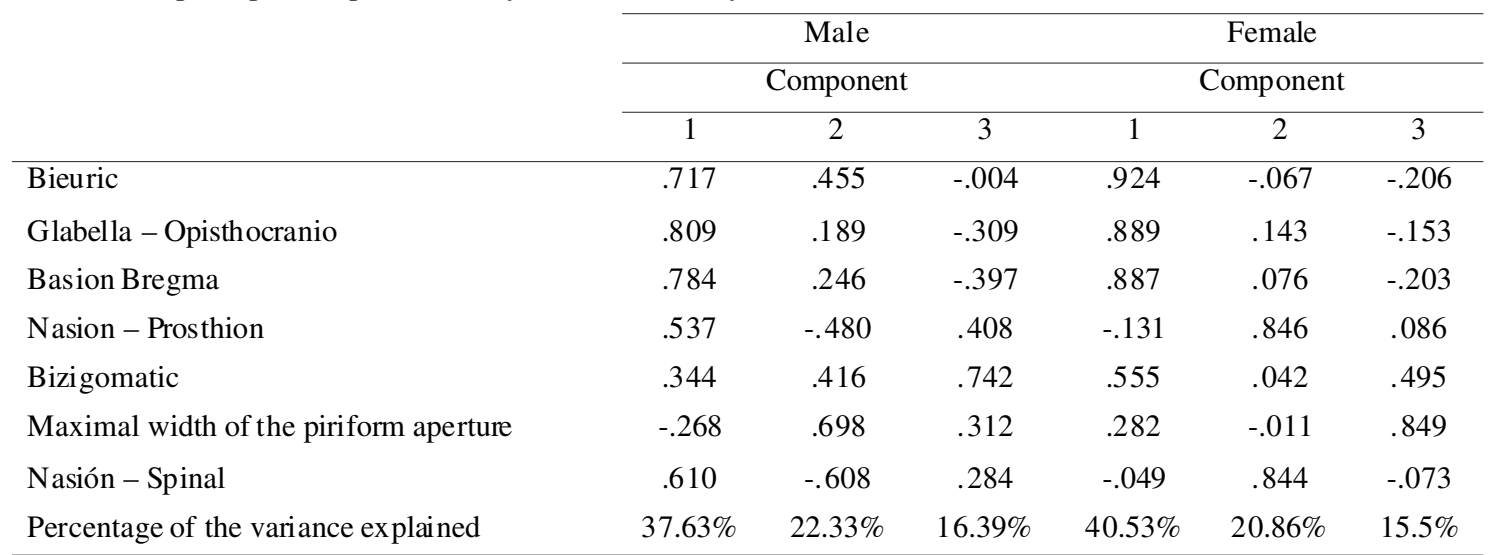

\section{DISCUSSION}

The quantitative methods used for the determining sex based on the lineal dimensions of the skull are constantly analyzed in diverse samples, in terms of accuracy and validity, to select appropriately those that allow the quantitative methods to be applied, or, to generate parameters peculiar to populations - specifically, in the context of the medico-legal identification.

In this study, some of the classic skull dimensions used to build indexes (cephalic, facial superior, nasal) and of wide application in formulas described to classify between men and women (Da Silva, 1997; Galvao, 2008) were analyzed. Some of these measures were significantly greater in the skulls of men (Gl-Op, Na-Pr, Zi-Zi and Na-ANS); however, when supplementing the study with the analysis of the discriminant function, it was observed that only $\mathrm{Zi}-\mathrm{Zi}$ and $\mathrm{Na}-\mathrm{ANS}$ allow to discriminate against with a success rate of $82.7 \%$ when classifying using these variables. In addition to the above-mentioned, with regard to the first three components, the principal components analysis of the sample can explain $76.36 \%$ and $76.9 \%$ of the variance in the skulls dimensions of men and women, respectively, the first of them being related with the size and remaining strongly associated to the shape in both men and in women, that is, the differences in the dimensions of the skulls can be explained by reason of size by $37.63 \%$ in men and $40.53 \%$ in women. This fact is interesting; the cranial size determination is multifactorial and because the splanchnocranium and the calvaria of the neurocranium development reaches mature dimensions influenced by epigenetics factors of high variability among populations, geographical regions, socioeconomic strata, and so on.

On the other hand, the remaining percentage of the variance is explained by differences in shape, especially facial. This is important and it reinforces the value of the dimorphism morphologic strains. In this respect, Suazo et al. (2008 a,b,c) reported good levels of accuracy of the qualitative classic strains of sexual dimorphism in a sample comparable to this study, a situation also described for other populations (Rogers, 2005; Haralabakis et al., 2006; Hu et al., 2006).

The authors conclude that the methods for determining sex based on the lineal dimensions of the skull present a limited utility as per this sample; new methods for sex determination should be explored. 
ZAVANDO, M. D. A.; SUAZO, G. I. C. \& SMITH, R. L. Determinación del dimorfismo sexual en las dimensiones lineales del cráneo. Int. J. Morphol., 27(1):133-137, 2009.

RESUMEN: La determinación del sexo a partir de cráneos humanos por métodos morfológicos cualitativos y morfométricos ha sido ampliamente estudiada. Éstos últimos se destacan por aportar datos objetivos; sin embargo, presentan variabilidad inter-poblacional. Los objetivos de este trabajo fueron: a) evaluar el dimorfismo sexual por medio de las dimensiones lineales, en una muestra de cráneos adultos pertenecientes a la Universidade Federal de São Paulo (UNIFESP); b) construir una función discriminante y c) evaluar su rendimiento. Se analizaron 226 cráneos que cumplieron los criterios de selección. Se realizaron las mediciones entre los siguientes puntos craneométricos: Eurion derecho- eurion izquierdo (Eu - Eu), Glabella- Opistocráneo (Gla - Op), Basion - Bregma (Ba-Br), Nasion - Prostion (Na-Pr), Bicigomática (Zi-Zi), Ancho máximo de la Apertura Piriforme (AMAP), Nasion - Espinal (Na-Es). Se calcularon estadísticos descriptivos e inferenciales (prueba t student $\mathrm{p}<0.05$, análisis de función discriminante) por sexo. Se establecieron diferencias estadísticamente significativas en las dimensiones $\mathrm{Gla}$ - Op, Na - Pro, Zi - Zi, Na - Es. Sólo las distancias Zi - Zi y NaEs fueron capaces de componer una función discriminante con un rendimiento del 82\%, para la correcta clasificación por sexo. Concluimos que las dimensiones lineales presenta una limitada utilidad para dimorfismo sexual en nuestra muestra.

\section{PALABRAS CLAVE: Puntos craneométricos; Cráneo; Dimorfismo sexual; Análisis de la función discriminante.}

\section{REFERENCES}

Abdelmalek, R.G. \& Michael, C.G. Sexual dimorphism in the mesiodistal width of the permanent maxillary anterior teeth in relation to their artificial replacements. Egypt. Dent. J., 30:107-18, 1984.

Balci,Y.; Yavuz, M.F. \& Cagdir, S. Predictive accuracy of sexing the mandible by ramus flexure. Homo, 55:229$37,2005$.

Baughan, B. \& Demirjian, A. Sexual dimorphism in the growth of the cranium. Am. J. Phys. Anthropol., 49:38390, 1978.

Bibby, R.E. A cephalometric study of sexual dimorphism. Am. J. Orthod., 76:256-9, 1979.

Buschang, P.H.; Tanguay, R.; Demirjian, A.; La Palme, L. \& Goldstein, H. Sexual dimorphism in mandibular growth of French-Canadian children 6 to 10 years of age. Am. J. Phys. Anthropol., 71:33-7, 1986.

Celbis, O.; Iscan, M.Y.; Soysal, Z. \& Cagdir, S. Sexual diagnosis of the glabellar region. Leg. Med. Tokyo., 3:16270, 2001.

Da Silva M. Compêndio de Odontologia Legal. Guanabara, Koogan, Rio de Janeiro, 1997.

de Paiva, L.A. \& Segre, M. Sexing the human skull through the mastoid process. Rev. Hosp. Clin. Fac. Med. Sao Paulo., 58:15-20, 2003.

Franklin, D.; Freedman, L. \& Milne, N. Sexual dimorphism and discriminant function sexing in indigenous South
African crania. Homo, 55:213-28, 2005.

Franklin, D.; Oxnard, C.E.; O'Higgins, P. \& Dadour, I. Sexual dimorphism in the subadult mandible: quantification using geometric morphometrics. J. Forensic Sci., 52:610, 2007.

Galvao, L.C. Medicina Legal. Ed. Santos, São Paulo, 2008.

Graw, M.; Czarnetzki, A. \& Haffner, H.T. The form of the supraorbital margin as a criterion in identification of sex from the skull: Investigations based on modern human skulls. Am. J. Phys. Anthropol., 108:91-6,1999.

Haralabakis, N.B.; Sifakakis, I.; Papagrigorakis, M. \& Papadakis, G. The correlation of sexual dimorphism in tooth size and arch form. World J. Orthod., 7:254-60, 2006.

Haun, S.J. Brief communication: a study of the predictive accuracy of mandibular ramus flexure as a singular morphologic indicator of sex in an archaeological sample. Am. J. Phys. Anthropol., 111:429-32, 2000.

Hu, K.S.; Koh, K.S.; Han, S.H.; Shin, K.J. \& Kim, H.J. Sex determination using nonmetric characteristics of the mandible in Koreans. J. Forensic Sci., 51:1376-82, 2006.

Introna, F. Jr.; Cantatore, F.; Dragone, M. \& Colonna, M. Sexual dimorphism of deciduous teeth in medico-legal identification. Boll. Soc. Ital. Biol. Sper., 69:223-30, 1993.

Kalmey, J.K. \& Rathbun, T.A. Sex determination by 
discriminant function analysis of the petrous portion of the temporal bone. J. Forensic Sci., 41:865-7,1996.

Kemkes, A. \& Gobel, T. Metric assessment of the "mastoid triangle" for sex determination: a validation study. $J$. Forensic Sci., 51:985-9, 2006.

Kimmerle, E.H.; Ross, A. \& Slice, D. Sexual dimorphism in america: geometric morphometric analysis of the craniofacial region. J. Forensic Sci., 53:54-7, 2008.

Kondo, S.; Townsend, G.C. \& Yamada, H. (). Sexual dimorphism of cusp dimensions in human maxillary molars. Am. J. Phys. Anthropol., 128:870-7, 2005.

Krogman, WM. The human skeleton in forensic medicine. Postgrad Med., 17:A48-72, 1955.

Lam, Y.M.; Pearson, O.M. \& Smith, C.M. Chin morphology and sexual dimorphism in the fossil hominid mandible sample from Klasies River Mouth. Am. J. Phys. Anthropol., 100:545-57,1996.

Lestrel, P.E.; Cesar, R.M. Jr.; Takahashi, O. \& Kanazawa, E. Sexual dimorphism in the Japanese cranial base: A Fourier-wavelet representation. Am. J. Phys. Anthropol., 128:608-22, 2005.

Loth, S.R. \& Henneberg, M. Mandibular ramus flexure: A new morphologic indicator of sexual dimorphism in the human skeleton. Am. J. Phys. Anthropol., 99:473-85, 1996.

Loth, S.R. \& Henneberg, M. Mandibular ramus flexure is a good indicator of sexual dimorphism. Am. J. Phys. Anthropol., 105:91-2, 1998.

Olivier, G. \& Tissier, H. Sexual dimorphism of correlations in craniometry. Bull. Assoc. Anat. Nancy., 61:259-67, 1977.

Panella, J.; de Freitas, A.; Varoli, O.J. \& da Silva, M. Sexual dimorphism in linear analysis of the mandible using elipsopantomographic pantomograms. Rev. Odontol. Univ. São Paulo., 2:92-6, 1988.

Rogers, T.L. Determining the sex of human remains through cranial morphology. J. Forensic Sci., 50:493-500, 2005.

Rosas, A.; Bastir, M.; Martinez-Maza, C. \& Bermudez de Castro, J.M. Sexual dimorphism in the Atapuerca-SH hominids: The evidence from the mandibles. J. Hum. Evol., 42:451-74, 2002.
Schleyer, F.; Ihm, P. \& Bensch, W. Sexual dimorphism of the outlines of the osseous orbit. Z. Rechtsmed., 69:168$72,1971$.

Schmittbuhl, M.; Le Minor, J. M.;Taroni, F. \& Mangin, P. Sexual dimorphism of the human mandible: Demonstration by elliptical Fourier analysis. Int. J. Legal Med., 115:100-1, 2001.

Steyn, M. \& Iscan, M. Y. Sexual dimorphism in the crania and mandibles of South African whites. Forensic Sci. Int., 98:9-16, 1998.

Suazo, G. I. C.; Zavando, M. D. A \& Smith, R. L. Evaluating accuracy and precision in Morphologic Traits for sexual dimorphism in malnutrition human skull: A comparative study. Int. J. Morphol., 26(4):876-83, 2008a.

Suazo, G. I. C.; Zavando, M. D. A \& Smith, R. L. Accuracy of palate shape as sex indicator in human skull with maxillary teeth loss. Int. J. Morphol., 26(4):989-93, 2008 b.

Suazo, G. I. C.; Zavando, M. D. A \& Smith, R. L. Sex determination using mastoid process measurements in Brazilian skulls. Int. J. Morphol., 26(4): 941-4, 2008c.

Ursi, W.J.; Trotman, C.A.; McNamara, J.A. Jr. \& Behrents, R.G. Sexual dimorphism in normal craniofacial growth. Angle Orthod., 63:47-56,1993.

Wescott, D.J. \& Moore-Jansen, P.H. Metric variation in the human occipital bone: forensic anthropological applications. J. Forensic Sci., 46:1159-63, 2001.

Correspondence to:

Dra. Daniela Zavando Matamala

Email: dzavando@yahoo.es

Received: 21-12-2008

Accepted: 07-01-2009 
